\title{
Cabo Verde: literatura em chão de cultura, de Simone C. Gomes
}

Rosangela SARTeschi

Universidade de São Paulo

s laços entre Brasil e países da África de língua portuguesa são antigos e fortes em decorrência da própria história.

Como se sabe, inicialmente essas relações foram pautadas pela violência do tráfico de escravos e das conseqüências nefastas sobre todas as sociedades envolvidas; com o decorrer do tempo, direcionaram-se, sobretudo, para o domínio da cultura. É por meio da leitura de textos literários dos países africanos que se percebe a força do Brasil "como uma das matrizes da utopia que seria fundamental na formação da consciência nacionalista que aqueceu as lutas de libertação nos países de língua portuguesa." (CHAVES, 2005: 266).

É inegável que a projeção de imagens do Brasil contribuiu para a formação de um pensamento nacionalista de países como Angola, Moçambique e Cabo Verde, principalmente. A cultura brasileira desempenhou papel agudo no processo de conscientização de setores intelectuais africanos, estabelecendo alternativas ao modelo do colonizador.

Em Cabo Verde há vários exemplos de como a circulação de projetos e idéias efetivou-se. O romance regionalista brasileiro, com sua temática da seca que expulsa o homem de sua terra com conseqüências que as aproxima do trágico, reverberou fortemente entre escritores cabo-verdianos, como Manuel Lopes e Baltasar Lopes.

Além dos prosadores, notam-se também influências brasileiras na produção artística de poetas do arquipélago. O grupo ligado à Claridade (1936) e, depois, à Certez̧a (1944) anunciava a questão da cabo-verdianidade através da literatura. Escritores e intelectuais projetavam um "esforço criador nos grandes segmentos que representavam ou simbolizavam a parte viva da sua 
pátria, ou seja, aquela que não dotava os critérios e os padrões que serviam ao colonialismo". (FERREIRA, 1987: 33).

$\mathrm{Na}$ esteira desses laços que se entrançam no bojo de uma língua e um projeto comuns, pesquisadores dos dois lados do atlântico empreenderam e empreendem esforços no sentido de constituir uma fortuna crítica em que se consolida trabalho de análise e interpretação das diferentes manifestações culturais dos países de língua oficial portuguesa.

O livro Cabo Verde: literatura em chão de cultura (GOMES, 2008), da pesquisadora e professora da USP, Simone Caputo Gomes, é uma grande contribuição nesse sentido.

Cabo Verde: literatura em chão de cultura reúne ensaios sobre literatura, música e artes plásticas cabo-verdianas, revelando a agudeza de espírito da autora e sua trajetória intelectual de uma vida dedicada ao ensino, à pesquisa e à divulgação da cultura daquele país. O livro está estruturado em três seções que retomam unidades temáticas basilares da cultura do arquipélago: o milho, o batuque, o vulcão.

A seção primeira - "Milho: semeando caminhos" - é constituída por cinco ensaios: "Voltando ao começo: a poesia viva de Daniel Filipe - amor e liberdade propagados com caráter de urgência nos weblogs do século XXI", "Presença de Amílcar Cabral na literatura da África de língua portuguesa e crioula", "A poética crioula de Sérgio Frusoni", "Os Avatares das Ilhas, de Danny Spínola" e "Cabo Verde e Brasil: um amor pleno e correspondido".

No texto que abre o capítulo e que trata da obra do poeta e jornalista Daniel Filipe, "construida na metrópole mas que busca dar visibilidade a temas e questões pertinentes à sua cultura de origem" (GOMES, 2008: 33), a autora analisa a recepção da obra filipiana, permeada por temas como o amor, o desejo de liberdade, a resistência à opressão no âmbito do indivíduo e do coletivo, o exílio, a busca das origens, o "terra-longismo", entre leitores da contemporaneidade que circulam pelos chamados weblogs, entrelaçando suas análises com intertextos virtuais e também com aqueles em que se estabelecem diálogos com outros escritores tais quais João Cabral de Melo Neto e Francisco José Tenreiro

Como nos lembra a autora, "o receptor estabelece com a poesia, no plano real, por meio virtual, aquela relação que todo escritor aspira ter com seu leitor: a compreensão do texto e, mais além, a sua cumplicidade afetiva" (GOMES, 2008: 36). 
O segundo texto, "Presença de Amílcar Cabral na literatura da África de língua portuguesa e crioula", como o próprio título indica, traça, por um lado, o percurso de vida de Amílcar Cabral, seu trabalho político, poético e estético. Por outro, esquadrinha a construção do mito heróico pela pena de variados escritores como Gabriel Mariano, Alda Espírito Santo e Emanuel Braga Tavares, que em crioulo firma e afirma a imortalidade de Cabral:

Kabral ka morrê

Ki kudi monte namonte na lém na Kobom

Pâ tudo banda ah Kabral !...

Alêbo firmina kada nôris

N’tom bo stábibo Kabral ka morrê!

Kabral ê noti!

Kabral ê koncéncia!

Kabral ê bandera!

Kabral ê liberdadi

Cabral não morreu

E ecoou pelo monte pela encosta pelo vale Por todo lado ah Cabral

Em cada um de nós te afirmas,

Estavas vivo Cabral não morreu!

Cabral é noite!

Cabral é consciência!

Cabral é bandeira!

Cabral é liberdade!

(TAVARES apud GOMES, 2008: 93)

"A poética crioula de Sérgio Frusoni" trata-se de excelente trabalho acerca de um poeta ainda muito pouco estudado. Sua importância, como nos aponta 
a pesquisadora, recai não somente sobre o fato de ter escrito sempre em "crioulo", língua que dominou com maestria, mas porque a sua produção se situa, verdadeiramente, em todas as esferas da poesia: lírica, romântica, de manifestação crítica: é um poeta que reflete a partir de sua terra. Estão presentes na sua poética a identidade de cabo-verdiano e sanvicentino, o binômio emigração/regresso, as saudades da terra natal, o lirismo, a exaltação dos costumes da terra, a seca, a fome, a questão da sobrevivência, o resgate da memória e da figura da mulher nesse contexto de dor e abandono, mas ainda plena de sensualidade.

Lembra-nos Simone Caputo Gomes que os poemas de Frusoni em crioulo são muito utilizados como letras de mornas, evidenciando uma vez mais a constante intersecção da poesia e da música no arquipélago.

Em Os Avatares das Ilhas, de Danny Spínola, a autora brinda-nos com uma afiada apresentação do romance, que, na melhor tradição da literatura comprometida do arquipélago, retrata "o percurso histórico do povo cabo-verdiano, herói (e anti-herói) um pouco ao jeito de uma saga, ao mesmo tempo que retrata a sua cultura e idiossincrasia", como ressalta o próprio autor (GOMES, 2008: 108).

Fechando essa primeira seção do livro, temos o ensaio "Cabo Verde: um amor pleno e correspondido". A dedicatória a Manuel Ferreira e Luis Romano além do texto em epígrafe de Ernesto Lara Filho acerca da influência exercida pela cultura brasileira (literatura e música) na vida cultural angolana dão a exata perspectiva do seu conteúdo: a estreita relação que se estabelece entre os escritores e artistas de lá e de cá em constantes movimentos de aproximações iniciados nas décadas de 1930 e 1940, apontando como o modernismo brasileiro, com sua pauta estética, ecoou de forma profícua no estabelecimento de um projeto de fundação de uma literatura nacional no outro lado do atlântico.

A segunda seção, "Batuque: encontrando som e sintonia", estrutura-se a partir de elemento constitutivo da identidade do arquipélago: o batuque ( $b a$ tuku ou batuk em crioulo cabo-verdiano), que é um ritmo que se estrutura a partir de um canto-resposta, apresentando uma polirritmia - emprego simultâneo de duas ou mais estruturas rítmicas diferentes em sua constituição. Já como dança, o batuque tradicional desenrola-se segundo um ritual preciso constituído por dois movimentos: em uma sessão de batuque, um conjunto 
de intérpretes - na maioria das vezes composto apenas por mulheres - organiza-se em círculo em um cenário chamado terreru.

Nesse sentido, os quatro ensaios que compõem essa seção - "A poesia em Cabo Verde: um trajeto identitário", "Ecos da cabo-verdianidade: literatura e música no arquipélago", "Cabo Verde: mulher, cultura, literatura" e "Manuel Lopes: o nascimento de Vênus, a genêse da cultura e da literatura em Cabo Verde" - têm como fio condutor a questão identitária na perspectiva trabalhada por Stuart Hall, para quem a nação é sistema de representação cultural além de entidade política, ou seja, é composta de representações e símbolos que fundamentam a constituição de uma dada identidade nacional. As culturas nacionais produzem, assim, sentidos que tornam possível a construção das identidades. Esses sentidos estão contidos em histórias, memórias e imagens que servem de referências, de nexos para a constituição de uma identidade da nação.

Os dois primeiros textos mostram como poesia e música têm papel substantivo na expressão da cultura e da identidade crioulas: o batuque, as mornas, as cantigas de trabalho, o funaná, a tabanca "se somavam à resistência organizada que desencadeou as lutas de libertação nacional” (GOMES, 2008: 127).

A autora destaca, assim, textos poéticos, que abrangem um extenso período: parte do século XIX (Pedro Cardoso, Eugénio Tavares e José Lopes), passa pela geração da Claridade e pelo grupo que lhe seguiu (Jorge Barbosa e Baltasar Lopes e, depois, Ovídio Martins) e alcança, finalmente, representantes da novíssima geração (Vera Duarte, Dina Salústio e David Hopffer Almada), em que temas, ritmos, costumes, crenças são retomados em um trabalho ético e estético de construção de uma poesia marcadamente "de pés fincados" nas ilhas do arquipelago.

Homens mulheres e crianças

Na pátria livre libertada

Plantando mil milharais

Serão a chuva caindo

Na nossa terra explorada

(DUARTE apud GOMES, 2008: 141)

No terceiro ensaio, a questão identitária passará pelo feminino: se por um lado a construção desse discurso ocorre pela via da solidão e do abandono, 
por outro, realça-se o papel das mulheres, responsáveis que são pela memória cultural: o ato de contar, nas sociedades marcadas pela oralidade, mais do que presentifícar a tradição, significa transmitir as experiências da ancestralidade em seu percurso pelo mundo material e imaterial.

Como portadores da voz no mundo, conforme define Paul Zumthor, os contadores assumem, junto às comunidades em que estão inseridos, os papéis de detentores públicos de uma voz que mantêm o laço social da comunidade.

No derradeiro ensaio, uma justa homenagem a Manuel Lopes: Simone Caputo Gomes entrelaça literatura, pintura e música para rememorar a obra fundadora com suas "imagens genesíacas" de um dos mais importantes escritores de Cabo Verde.

Ao abordar o paradigmático conto "Galo cantou na Baía”, a pesquisadora ressalta:

Unindo os elementos, essa imagem de Vénus, além de evocar toda uma tradição estética que perpassa a escultura e a pintura ocidentais, alia-se ainda à Vénus Estrela de Alva, que prenuncia o cantar do galo ("Já é madrugada, o sol vem perto”), momento de culminância da criação poético-musical. (GOMES, 2008: 188)

A terceira seção - "Vulcão: soltando a voz" - destaca um terceiro elemento de identificação do arquipélago: o vulcão, cuja erupção abala a própria firmeza da terra, associa-se aqui ao discurso feminino que, em certa medida, vem abalar o cânone fundamentalmente masculino do arquipélago.

Nos quatro primeiros textos dessa seção - "Mulher com paisagem ao fundo: Dina Salústio apresenta Cabo Verde", "Ainda e sobretudo a paixão: o Arquipélago da paixão, de Vera Duarte", "Preces e súplicas ou Os cânticos da desesperança, de Vera Duarte" e "Lição de crônica: um certo olhar de Fátima Bettencourt sobre Cabo Verde", a pesquisadora convoca três importantes vozes femininas contemporâneas - Dina Salústio, Vera Duarte, Fátima Bettencourt - como anunciadoras da inscrição do feminino no discurso literário caboverdiano, em que se apresentam textos de intensa vibração erótica, de consciência do corpo e de afirmação do desejo conformadas pela especificidade da escrita e intensa experimentação estética. Esse discurso feminino marcado pela diversidade e pela busca identitária problematiza o mundo sob uma nova 
ótica, resultando, na obra das três autoras, na "reinvenção das ilhas pela literatura" (GOMES, 2008: 230).

No ensaio que encerra a seção e também o livro, "O texto literário de autoria feminina escreve e inscreve a mulher e(m) Cabo Verde", a autora desenha um painel do percurso feminino não apenas no plano da arte e cultura cabo-verdianas, mas também no político-social como força motriz da construção da nação por meio de instigantes painéis e cenas a partir de excertos das obras das diferentes escritoras - prosadoras, cantadoras e poetas crioulas - construindo, assim, um quadro do qual a vida do arquipélago desprende-se, pulsante e enérgica.

Como finaliza Simone Caputo Gomes, "as mulheres cabo-verdianas agora recortam a realidade segundo as suas vivências cotidianas, assumindo o seu protagonismo, a diagonal do seu olhar e a sua própria voそ’" (GOMES, 2008: 300).

\section{Referências Bibliográficas}

CHAVES, R. Angola e Moçambique - experiência colonial e territórios literários. São Paulo: Ateliê, 2005.

FERREIRA, M. Literaturas africanas de expressão portuguesa. São Paulo: Ática, 1987.

GOMES, S. C. Cabo Verde: literatura em chão de cultura. São Paulo: Ateliê, 2008. 312 p. HALL, S. A identidade cultural na pós-modernidade. Rio de Janeiro: DP\&A, 2005.

ZUMTHOR: A letra e a voz: São Paulo: Companhia das Letras, 1993. 